\title{
Seed Distribution Mechanisms and Sowing Speed on Plantability and Agronomic Characteristics of Sunflower
}

\author{
Flávio Carlos Dalchiavon ${ }^{1}$, Davi Antonio Pedrini Marcondes ${ }^{1} \&$ Claudio Guilherme Portela Carvalho ${ }^{2}$ \\ ${ }^{1}$ Department of Agronomy, Federal Institute of Education, Science and Technology of Mato Grosso, Campo \\ Novo do Parecis, MT, Brazil \\ ${ }^{2}$ Brazilian Agricultural Research Corporation, Embrapa Soybean, Londrina, PR, Brazil \\ Correspondence: Flávio Carlos Dalchiavon, Department of Agronomy, Federal Institute of Education, Science \\ and Technology of Mato Grosso, 78360-000, Campo Novo do Parecis, MT, Brazil. Tel: 55-65-99617-5059. \\ E-mail: flavio.dalchiavon@cnp.ifmt.edu.br
}

Received: September 16, 2019

Accepted: November 12, 2019

Online Published: March 15, 2020

doi:10.5539/jas.v12n4p119

URL: https://doi.org/10.5539/jas.v12n4p119

\begin{abstract}
Precision in sowing is an important strategy for increasing agricultural yield. The objective of this study was to evaluate the influence of seed distribution mechanisms and sowing speeds on characteristics of sunflower. The experiment was set in March 2015 in São José do Rio Claro, state of Mato Grosso (Brazil). The experimental design was a completely randomized block design, in a $2 \times 5$ factorial arrangement, with two seed distribution mechanisms (perforated and pneumatic disc) and five sowing speeds $\left(4 ; 6 ; 8 ; 10\right.$ and $12 \mathrm{~km} \mathrm{~h}^{-1}$ ) with four repetitions. The vegetative and reproductive characteristics of the sunflower were evaluated and also the double, faulty and acceptable spacing were evaluated to observe the homogeneity of seed distribution through the sowers. Regardless of the seed distribution mechanism, the rise in the sowing speed caused a reduction in plant population by changing plant height, head height, head mass, achene mass per head, mass of one thousand achenes and head diameter. The perforated disk distribution mechanism showed the best performance in acceptable spacings and the pneumatic one provided a greater guarantee of the desired plant population. The different distribution mechanisms, as well as different sowing speeds, did not influence achenes yield. The farmer should be aware of the speed of sowing adopted in his sunflower crop, as increasing speeds may affect uniform seed distribution as well as plant development.
\end{abstract}

Keywords: agriculture mechanization, Helianthus annuus L., precision seeding, tractor-sower set

\section{Introduction}

The sunflower cultivation area has largely expanded in Brazil due to the establishment of achenes processing industries in producing regions, adequate oil yield for food industries, increase in the crop production technology, cultivars with acceptable adaptability and stability in growing conditions, early cycle and satisfactory yield to the producer (Furtado \& Chaves, 2018; Dalchiavon, Lorenzon, Perina, Oliveira, \& Santos, 2019).

Among the production technologies, sowing is considered one of the most important operations for enhancing crop productivity. However, such operation has to be performed with quality and precision (Alonço, Silveira, Cardinal, \& Rist, 2015). According to Rosa et al. (2012), inadequate seed distribution has been increasingly observed, resulting in losses in achenes productivity, corroborating what Portella (2001) had already estimated, that losses due to lack of uniformity in sowing can reach $35 \%$ in sunflower crop.

Lack of uniformity in sowing is treated as plantability, defined as the precise distribution of seeds in terms of quantity and distance between them (Krzyzanowski, França-Neto, Hennning, \& Costa, 2008). Higher efficiency in crop sowing may contribute to increase their productivity by enabling a better use of water, light, space and nutrients available in the soil. When crops are not properly planted, two problems are detected: the appearance of double spaces, favoring intraspecific competition and faulty spaces that will be occupied by weeds (Bottega, Rosolem, Oliveria Neto, Piazzetta, \& Guerra, 2014).

For sunflower sowing, horizontal (perforated) mechanical disk meters and pneumatic vacuum meters are mostly used (Alonço et al., 2015). The displacement speed of the seeder is one of the characteristics that has the greatest influence on uniformity of distribution and mechanical damage of seeds (Silva \& Gamero, 2010), which may 
compromise the controlling of pests, diseases, weeds and maintenance of soil fertility. This uniformity of longitudinal seed distribution is the factor that most contributes to achieving an adequate plant stand and, consequently, better crop yields (Krzyzanowski et al., 2008).

When evaluating different seed distribution mechanisms (horizontal and pneumatic disc), displacement speed and soil cover conditions in soybean crop, Pinheiro Neto et al. (2008) concluded that by increasing the displacement speed, the plant population in the area and the percentage of acceptable spacing decrease, directly reflecting on the plant yield performance. Garcia et al. (2011) also observed that the rise in the displacement speed caused an increase in the peripheral velocity of the seed distribution disc, resulting in double spacing, decrease of seeds distributed per meter and increase of exposed seeds. The authors also observed that the passage of seeds through the distribution mechanism at high speed caused mechanical damage to the seeds, reducing the germination percentage.

However, studies of this nature using sunflower crop in Brazil do not exist and are rare worldwide. In this sense, the objective of this work was to evaluate the influence of seed distribution mechanisms and sowing velocities on characteristics of sunflower.

\section{Method}

The experiment was carried out from March to July 2015, in the municipality of São José do Rio Claro, state of Mato Grosso (Brazil), within the following geographical coordinates: latitude $13^{\circ} 44^{\prime} 66^{\prime \prime}$ south and longitude $57^{\circ} 12^{\prime} 86^{\prime \prime}$ west, 506 meters above sea level. The soil in the experimental area is classified as a typical dystrophic Red-Yellow Latosol with a clay texture (Empresa Brasileira de Pesquisa Agropecuária [EMBRAPA], 2018). The local climate, according to Köppen's classification, is Aw, tropical climate with a well-defined dry season from May to September.

The experimental design was randomized blocks in a $2 \times 5$ factorial arrangement with two seed distribution mechanisms (perforated and pneumatic disc) and five tractor-sower set displacement speeds $(4,6,8,10$ and 12 $\mathrm{km} \mathrm{h}^{-1}$ ), with four repetitions.

The experiment was set in no-tillage system in succession to soybean crop. The experimental plots consisted of ten sowing rows, spaced by $0.45 \mathrm{~m}$ and $30 \mathrm{~m}$ long. The six central lines were considered usable area, discarding five meters at each end as a border, resulting in a usable area of $54 \mathrm{~m}^{2}$ per plot. The sowing density was set to 47280 seeds ha ${ }^{-1}$.

Sowing was performed on March 20, 2015 using a John Deere 1111 seeder equipped with the pneumatic meter system with negative pressure and a Semeato Sol Tower seeder equipped with the perforated disc meter system. Considering that one of the obstacles to the adoption of the no-tillage system is the difficulty of seeders to break the straw layer on the soil (Trogello et al., 2014), the amount of straw was quantified at sowing, with an average value of $3.42 \mathrm{tha}^{-1}$ dry mass.

The area was desiccated with the aid of a self-propelled sprayer with an application volume of $100 \mathrm{~L} \mathrm{ha}^{-1}$, using glyphosate (480 $\mathrm{g} \mathrm{L}^{-1}$ acid equivalent) at a dose of $1.5 \mathrm{~L} \mathrm{ha}^{-1}$ of the active ingredient combined with a liquid fertilizer containing 10\% Boron (B), $1 \%$ Molybdenum (Mo) and 7.8\% Zinc (Zn) at a dose of three $\mathrm{kg} \mathrm{ha}^{-1}(300 \mathrm{~g}$ $\left.\mathrm{ha}^{-1} \mathrm{~B}\right)$.

The sunflower variety used in the experiment was Syn 045, with the industrial sieve classified as G3, with an average diameter of $5.0 \mathrm{~mm}$. Graphite was added to the seeds to increase fluidity and improve soil distribution. Based on the soil chemical analysis, sowing fertilization was 30,80 and $40 \mathrm{~kg} \mathrm{ha}^{-1}$ of $\mathrm{N}, \mathrm{P}_{2} \mathrm{O}_{5}$ (MAP) and $\mathrm{K}_{2} \mathrm{O}$ $(\mathrm{KCl})$. At 30 days after emergence (DAE), topdressing fertilization was performed using $200 \mathrm{~kg} \mathrm{ha}^{-1}$ of formula 30-00-20 (N- $\left.\mathrm{P}_{2} \mathrm{O}_{5}-\mathrm{K}_{2} \mathrm{O}\right)$.

Monitoring and control of the helicoverpa (Helicoverpa sp.), soybean looper (Chrysodexis includens), Cucurbit Beetle (Diabrotica speciosa) and Cyclocephala melanocephala were performed using the insecticides profenofos + lufenurom $\left(0.4 \mathrm{~L} \mathrm{ha}^{-1}\right)$ and thiametoxam + lambda-cyhalothrin $\left(0.3 \mathrm{~L} \mathrm{ha}^{-1}\right)$. Fungicides Azoxystrobin + cyproconazole $\left(0.3 \mathrm{~L} \mathrm{ha}^{-1}\right)$ were also used at 38 and $50 \mathrm{DAE}$ to control alternaria spot (Alternaria helianthi) and white mold (Sclerotinia sclerotiorum), with application volume of $150 \mathrm{~L} \mathrm{ha}^{-1}$. Post-emergence weed control was performed at $24 \mathrm{DAE}$ through manual weeding. Flowers in the useful area were protected against attacks of birds using non-woven fabric (TNT).

The vegetative characteristics evaluated in five plants marked at full flowering (R5.5) were the plant height, measured from the ground level at the flower insertion, and the stem diameter at five centimeters from the ground level. 
The reproductive characteristics evaluated at R5.5 were the green mass and dry mass of five continuous plants (stem, leaf + petiole and head), which were weighed at the wet basis and then at dry basis after drying in forced air circulation oven at $65^{\circ} \mathrm{C}$ until constant weight, based on the total plants contained in the two 5-m centerlines at physiological maturity (R9). At R9 (harvest, July 10) the head height from the ground level to the base of the head, head diameter, head mass, achene mass per head, achene/head ratio and the mass of one thousand achenes were weighed and moisture corrected to $11 \%$ (wet basis - w.b.). The achenes yield was determined based on the heads collected in the useful area of each plot, using scissors to cut them and a thresher to separate the achenes (11\% w.b.).

Plant longitudinal distribution was measured at 16 days after sowing, by noting the number of double plant distribution, faulty and acceptable plant distribution, which were analyzed according to agronomic recommendations for sunflower crop (Associação Brasileira de Normas Técnicas [ABNT], 1995) by means of Table 1, using $0.47 \mathrm{~m}$ as the reference spacing (Xref).

Table 1. Control intervals for the spacing between plants

\begin{tabular}{ll}
\hline Spacing type & Tolerance range for "X" \\
\hline Multiples $<0.5$ Xref & $\mathrm{X}<23.5$ \\
0.5 Xref $<$ Acceptable $<1.5$ Xref & $23.5<\mathrm{X}<70.5$ \\
Failure $>1.5$ Xref & $\mathrm{X}>70.5$ \\
\hline
\end{tabular}

Source: Adapted from ABNT (1995).

Data were subjected to analysis of variance by the F-test and, when significant, the Tukey test was used to compare seed distribution mechanisms and regression analysis for tractor-sower set displacement speeds, both at $5 \%$ probability $(\mathrm{p}<0.05)$, using the statistical software SISVAR (Ferreira, 2011).

\section{Results and Discussion}

There was a significant effect of seed distribution (DM) for six traits evaluated and significant effect of sowing speed (SS) for eight traits (Table 2). There was interaction between DM and SS only for plant height, head height and achene mass per head (Table 2), indicating that, for these characteristics, the difference between distribution mechanisms must be analyzed for each sowing speed and the influence of the velocity on each distribution mechanism. For the other characteristics, the behavior of one factor did not depend on the levels of the other.

Table 2. Analysis of variance for agronomic traits of sunflower sown at different speeds and different seed distribution mechanisms (São José do Rio Claro, MT, 2015)

\begin{tabular}{llllll}
\hline \multirow{2}{*}{ Characteristic } & \multicolumn{3}{c}{ Sources of Variation } \\
\cline { 2 - 6 } & Seed distribution mechanism (DM) & Sowing speed (SS) & DM * SS & CV (\%) & Mean \\
\hline Plant population (POP) & $20.8^{* *}$ & $7.1^{* *}$ & 1.7 & 8.0 & 45925 \\
Plant height (PH) & 0.8 & $5.0^{* *}$ & $6.5^{* *}$ & 3.7 & 190.0 \\
Stem diameter (SD) & $14.3^{* *}$ & 2.0 & 1.9 & 4.9 & 21.9 \\
Green mass (GM) & 0.1 & 1.9 & 0.8 & 21.2 & 31.2 \\
Dry mass (DM) & 3.1 & 1.5 & 2.5 & 19.5 & 3.7 \\
Head height (FHH) & $5.3^{*}$ & $3.3^{*}$ & $4.6^{* *}$ & 3.8 & 155.6 \\
Head mass (FHM) & 2.5 & $2.8^{*}$ & 2.3 & 12.1 & 81.5 \\
Head mass achene (MFA) & 0.9 & $4.4^{* *}$ & $4.8^{* *}$ & 10.9 & 56.2 \\
Achene/head rate (AFHR) & 0.1 & $2.5^{* *}$ & 2.3 & 1.9 & 0.68 \\
One thousand achene mass (TAM) & 0.4 & $3.0^{*}$ & 1.6 & 5.3 & 68.1 \\
Head diameter (FHD) & $5.9^{* *}$ & $3.7^{*}$ & 1.1 & 4.8 & 109.7 \\
Achene yield (AY) & 1.2 & 2.2 & 0.6 & 12.7 & 1820.3 \\
Double & $21.1^{* *}$ & 2.5 & 2.4 & 95.3 & 8.7 \\
Faulty & 0.5 & 0.6 & 0.6 & 75.7 & 12.3 \\
Acceptable & $13.3^{* *}$ & 1.1 & 2.6 & 14.7 & 78.7 \\
\hline
\end{tabular}

Note. ${ }^{* *}$ and ${ }^{*}$ significant at 1 and $5 \%$ probability by the $\mathrm{F}$ test, respectively, and $\mathrm{CV}=$ Coefficient of variation. 
There were no significant differences between seed distribution mechanisms and between sowing velocities for green mass, dry mass, achenes yield and failures (Table 2). Their average values were $31.2 \mathrm{t} \mathrm{ha}^{-1}, 3.7 \mathrm{t} \mathrm{ha}^{-1}$, $1820.3 \mathrm{~kg} \mathrm{ha}^{-1}$ and 12.3 , respectively. The coefficients of variation are within acceptable range, less than $30 \%$, except for doubles $(95.3 \%)$ and failures $(75.7 \%)$, according to the limits defined by Pimentel Gomes and Garcia (2002). The high coefficients obtained for these characteristics may have resulted from the occurrence of double spacing, caused by faults and double seed positioning, which is common according to Bottega et al. (2014).

The statistical non-difference for achene yield may have occurred due to the plasticity of the sunflower in compensating productivity with change in the population, which was not evidenced by Portella (2001), who reported the lack of uniformity in sowing as one of the factors that may result in yield losses of up to $35 \%$ for sunflower.

The largest plant populations were found in the pneumatic mechanism as this mechanism has a greater number of double spacing (Table 3), in addition to the damage caused to seeds by perforated disk distribution mechanism, reducing germination by $2.8 \%$ and thus reducing the plant population, relationship also evidenced by Vale, Garcia, Corrêa Júnior, Gravina, and Klaver (2010). The higher incidence of doubles observed for the pneumatic distribution mechanism can be explained by the fact that the sunflower seed is light, representing difficulty in regulating the seeder vacuum pressure, thereby, favoring the appearance of double spacing. However, it is emphasized that other factors may interfere in the double spacing such as the soil turnover index, the straw breaking capacity and, mainly, the tractor-seeder set wear index.

Table 3. Mean values for the agronomic traits of sunflower sown at different seed distribution mechanisms (São José do Rio Claro-MT, 2015)

\begin{tabular}{lll}
\hline Characteristics & Perforated disk & Pneumatic \\
\hline Plant population $\left(\mathrm{pl} . \mathrm{h} \mathrm{h}^{-1}\right)$ & $43259 \mathrm{~b}$ & $48592 \mathrm{a}$ \\
Stem diameter $(\mathrm{mm})$ & $22.6 \mathrm{a}$ & $21.3 \mathrm{~b}$ \\
Head diameter $(\mathrm{mm})$ & $111.7 \mathrm{a}$ & $107.7 \mathrm{~b}$ \\
Double $(\%)$ & $2,7 \mathrm{~b}$ & $14.7 \mathrm{a}$ \\
Acceptable (\%) & $85.3 \mathrm{a}$ & $72.0 \mathrm{~b}$ \\
\hline
\end{tabular}

Note. ${ }^{*}$ Equal lower-case letters on the line are not different from each other by the Tukey test $(\mathrm{p}<0.05)$.

Both seed distribution mechanisms presented variation range (real/observed population versus desired/regulated population) within the acceptable ranges, according to the proposition of Siqueira and Casão Junior (2002) who cite values up to $\pm 10 \%$, since such variations were 9 (perforated disc) and $3 \%$ (pneumatic disc) (Table 3 ).

The pneumatic disk distribution system provided lower values for stem and head diameters of sunflower plants (Table 3) since that system tend to have larger plant populations and, consequently, greater intraspecific competition, therefore, decreasing due to etiolating of plants, stem and head diameters, as observed by Bezerra, Dutra, Bezerra, Oliveira Filho, and Barros (2014), as well as for the phenotypic plasticity of the plant to the conditions of its habitat. Larger plant populations, or uneven distributions in sowing, may imply in the inefficient use of available environmental resources (light, water and nutrients) with direct reflection on the diameters of the stem and head (Pinheiro Neto et al., 2008).

The perforated disk seeder had between 75 and $90 \%$ of acceptable spacing, therefore, it can be classified as good performance (Table 3), according to Tourino and Klingensteiner (1983), while the pneumatic distribution sower had regular performance (between 50 and $75 \%$ of acceptable spacing), mainly due to the high index of double spacing.

A quadratic decrease was observed in plant population as sowing speed increased (Figure 1a), with a reduction by $18 \%$ in sunflower plant population, when sowing speed increased from 4 to $10.37 \mathrm{~km} \mathrm{~h}^{-1}$ (minimum point). Silva, Kluthcouski, and Silveira (2000) also observed a decrease in the corn plant population as the sowing speed increased. On the other hand, the increase in the displacement speed did not vary the percentage of acceptable spacing (Table 2) and it was possible to obtain plant populations which were agronomically recommended for the two seed distribution mechanisms (Table 3), contrary to the results obtained by Pinheiro Neto et al. (2008). 
(a)

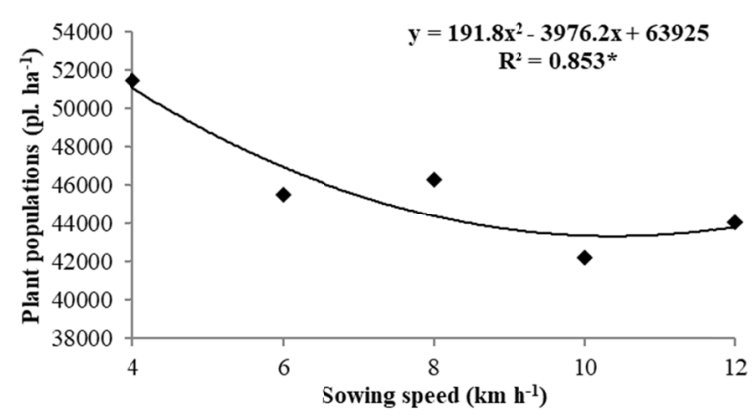

(c)

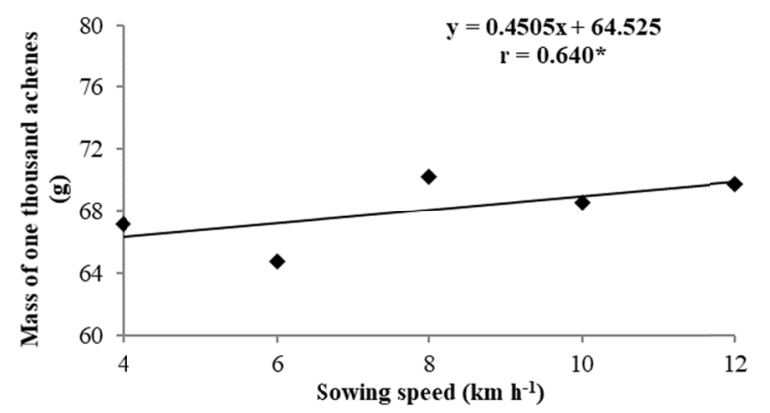

(b)

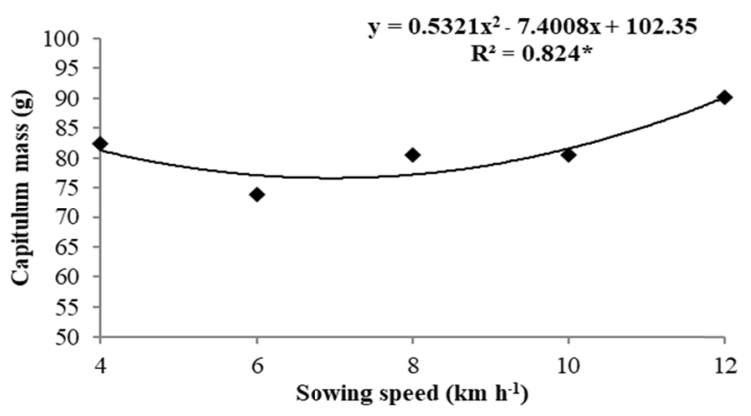

(d)

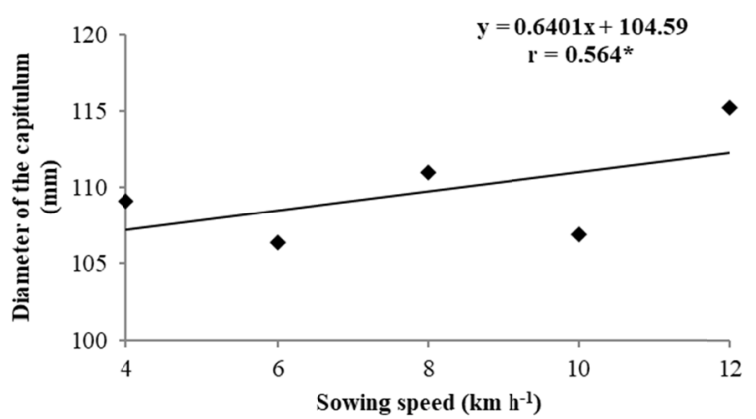

Figure 1. Regression equation for different plant populations (a) head mass (b), mass of one thousand achenes (c) and head diameter (d) according to sowing speed (São José do Rio Claro-MT, 2015)

The effect of sowing speed on head mass can be explained by a quadratic polynomial regression (Figure 1b), so that its minimum point was set at $6.95 \mathrm{~km} \mathrm{~h}^{-1}$. From this sowing speed, the mass of the head increased, due to the decrease in plant population as the displacement speed increases (Figure 1a), resulting in larger and heavier head, according to Pinheiro Neto et al. (2008), who observed that in smaller plant populations, there is larger space for leaf organization and growth, therefore reducing competition for light and promoting production components.

Both the mass of one thousand achenes and the head diameter showed a linear increase trend as the sowing speed increased (Figures 1c and 1d), facts explained by the decrease in the population due to failures (Table 3; Figure 1a) and a reduction in the competition, as reported by Castro, Junior, Oliveira, Leite, and Rodak (2011), that is, by the compensating-effect. The mass of a thousand achenes increased from 66.33 to $69.93 \mathrm{~g}(5 \%)$ when the sowing speed increased from 4 to $12 \mathrm{~km} \mathrm{~h}^{-1}$, while the head diameter capitulum increased by $5.12 \mathrm{~mm}$ (or $5 \%$ ), from 107.2 to $112.27 \mathrm{~mm}$ respectively.

The two seed distribution mechanisms provided similar heights for plant and head at 6 and $8 \mathrm{~km} \mathrm{~h}^{-1}$ sowing speeds (Table 4). For the other speeds, this characteristic varied according to the distribution mechanism. Lower plant height obtained for pneumatic system $\left(4\right.$ and $\left.10 \mathrm{~km} \mathrm{~h}^{-1}\right)$ and perforated disc $\left(12 \mathrm{~km} \mathrm{~h}^{-1}\right)$ is of great importance for sunflower crop as they can facilitate crop treatment and mechanized harvesting, as found in the studies of Dalchiavon, Malacarne, and Carvalho (2016), besides presenting lower rates of breakage in the occurrence of obstacles. Still in Table 4, it was verified that the achene mass per head showed some differences only for the sowing speeds of 8 and $10 \mathrm{~km} \mathrm{~h}^{-1}$, with the perforated disk seed distribution mechanism lower than 8 $\mathrm{km} \mathrm{h}^{-1}$, whereas for $10 \mathrm{~km} \mathrm{~h}^{-1}$, it was higher (Table 4). 
Table 4. Agronomic traits of sunflower sown at different sowing speeds using the same seed distribution mechanism (São José do Rio Claro-MT, 2015)

\begin{tabular}{lccccc}
\hline \multirow{2}{*}{ Seed distribution mechanism } & \multicolumn{5}{c}{ Sowing speed $\left(\mathrm{km} \mathrm{h}^{-1}\right)$} \\
\cline { 2 - 6 } & 4 & 6 & 8 & 10 & 12 \\
\hline Plant height $(\mathrm{cm})$ & $200.87 \mathrm{a}$ & $195.20 \mathrm{a}$ & $190.73 \mathrm{a}$ & $192.00 \mathrm{a}$ & $175.60 \mathrm{~b}$ \\
Perforated pneumatic disk & $190.13 \mathrm{~b}$ & $197.27 \mathrm{a}$ & $185.07 \mathrm{a}$ & $178.40 \mathrm{~b}$ & $193.80 \mathrm{a}$ \\
\hline Head height $(\mathrm{cm})$ & & & & & \\
Perforated pneumatic disk & $168.73 \mathrm{a}$ & $153.40 \mathrm{a}$ & $151.60 \mathrm{a}$ & $159.87 \mathrm{a}$ & $155.33 \mathrm{a}$ \\
\hline Achenes mass per head $(\mathrm{g})$ & $154.73 \mathrm{~b}$ & $158.20 \mathrm{a}$ & $152.40 \mathrm{a}$ & $145.73 \mathrm{~b}$ & $156.07 \mathrm{a}$ \\
& & & & & \\
Perforated pneumatic disk & $59.3 \mathrm{a}$ & $52.8 \mathrm{a}$ & $55.0 \mathrm{~b}$ & $60.5 \mathrm{a}$ & $58.3 \mathrm{a}$ \\
& $53.1 \mathrm{a}$ & $47.4 \mathrm{a}$ & $64.7 \mathrm{a}$ & $46.9 \mathrm{~b}$ & $64.3 \mathrm{a}$ \\
\hline
\end{tabular}

Note. * Equal lower-case letters are not different from each other by the Tukey test $(\mathrm{p}<0.05)$.

Plant height as well as the head height could be explained by regression models as a function of increasing sowing speed for the perforated disk distribution mechanism (Figures $2 \mathrm{a}$ and $2 \mathrm{~b}$ ), with a linear decrease in plant height from 201.6 to $180.1 \mathrm{~cm}$ as sowing speed raised from 4 to $12 \mathrm{~km} \mathrm{~h}^{-1}$. Probably the decrease in the plant population as the displacement speed was raised caused the decrease in the sunflower plant height. According to Castro et al. (2011), the increase in plant population raises their height, influenced by plant etiolating in search of sunlight. For the head height, the equation was quadratic, in which the highest value was observed at a speed of 4 $\mathrm{km} \mathrm{h}^{-1}(166.4 \mathrm{~cm})$, reducing to the minimum point of $8.9 \mathrm{~km} \mathrm{~h}^{-1}(152.8 \mathrm{~cm})$, and then increasing from this speed (Figures 2b).

(a)

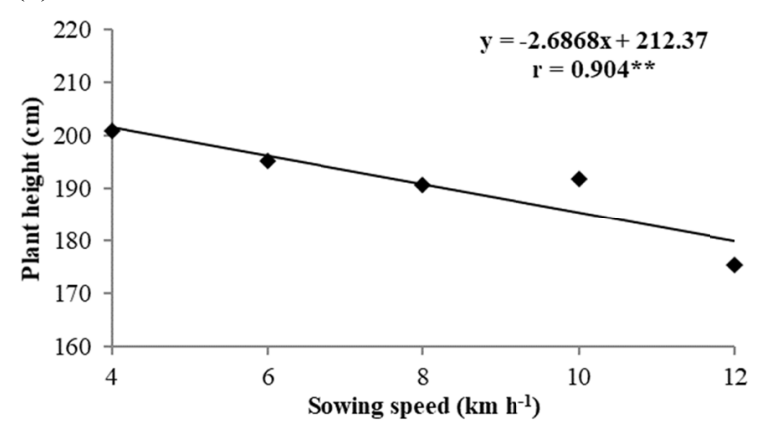

(c) (b)

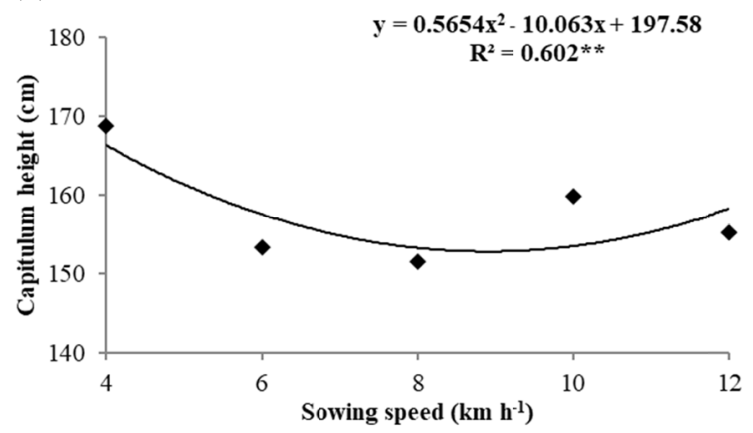

$y=1.0966 x+46.526$ $\mathrm{r}=0.396^{*}$

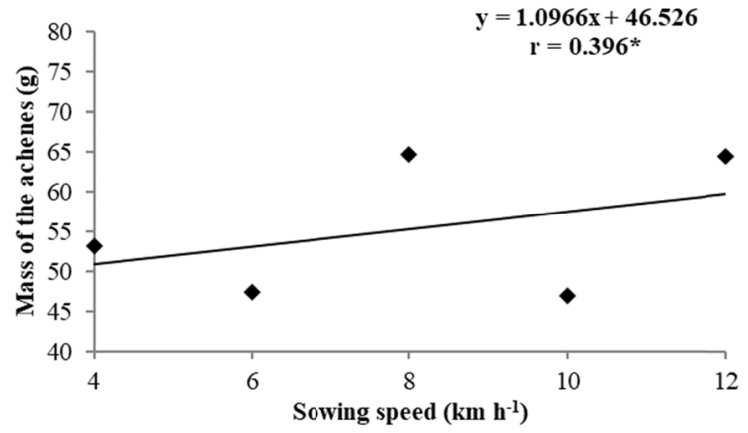

Figure 2. Regression equation for plant height (a), head height (b) and achene mass per head (c) according to sowing speed for perforated disk ( $a$ and $b$ ) and pneumatic distribution system (c)

(São José do Rio Claro-MT, 2015)

For the mass of the achene mass head (Figure 2c), a direct linear model was observed between effect (sowing velocities) and cause (achene mass per head) for the pneumatic distribution system despite the low correlation 
coefficient $\left(\mathrm{r}=0.396^{*}\right)$. Indeed, there was a tendency for the values to have increased as the sowing speed increased, so that the achene mass per head between 50.9 and $59.7 \mathrm{~g}$ when speeds increased from 4 to $12 \mathrm{~km} \mathrm{~h}^{-1}$, which was caused by the decrease in plant population linked to the increase in sowing speed.

It is possible to observe in the control charts (Figure 3) the variability of the spacing between plants of the perforated (DIS) and pneumatic disk (PNE) distribution mechanism, where the lines that exceed the upper control lines (LSC) indicate that the spacings between plants are over the maximum warning about faulty spacing. Likewise, when the lines fall below the lower control limits (LIC), they warn that the spacings are below the limits, indicating double spacings.

(a)

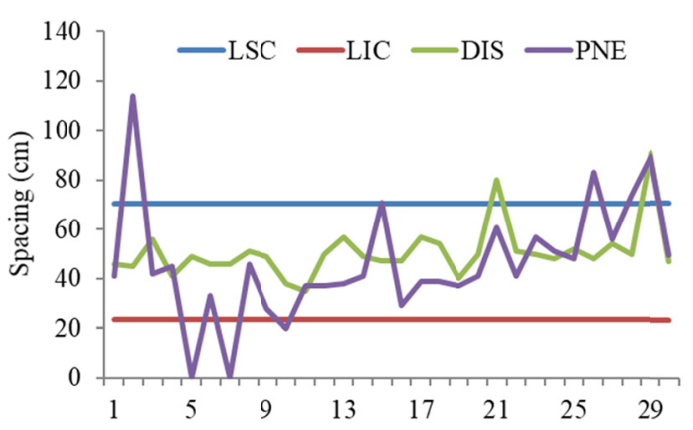

(c)

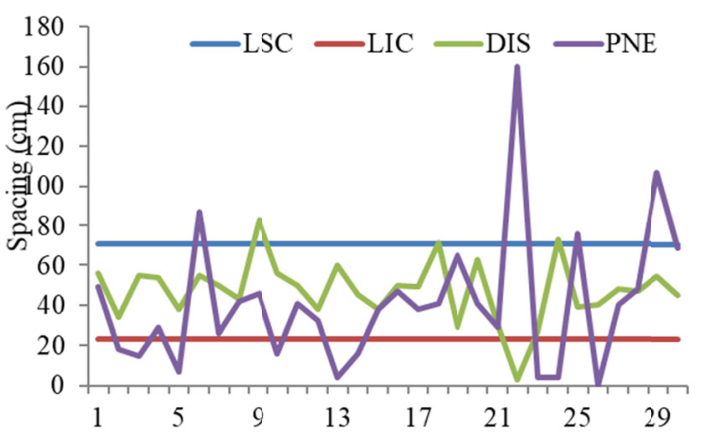

(b)

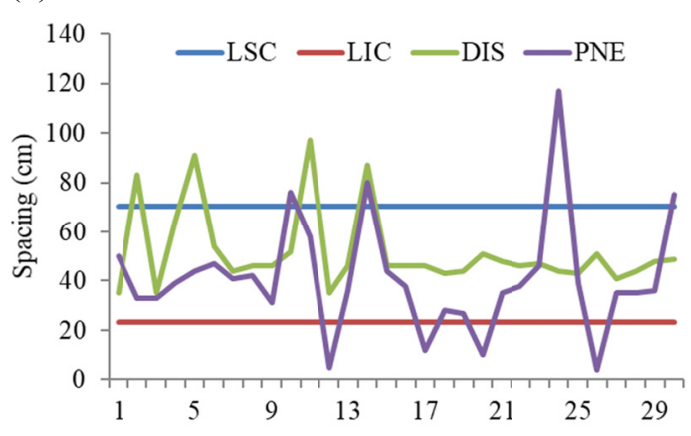

(d)

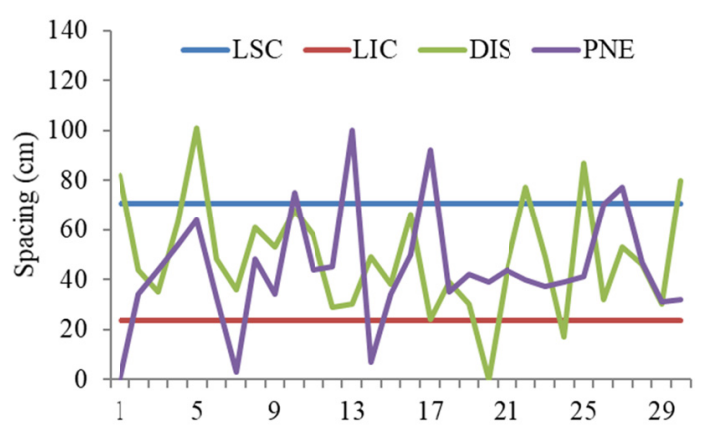

(e)

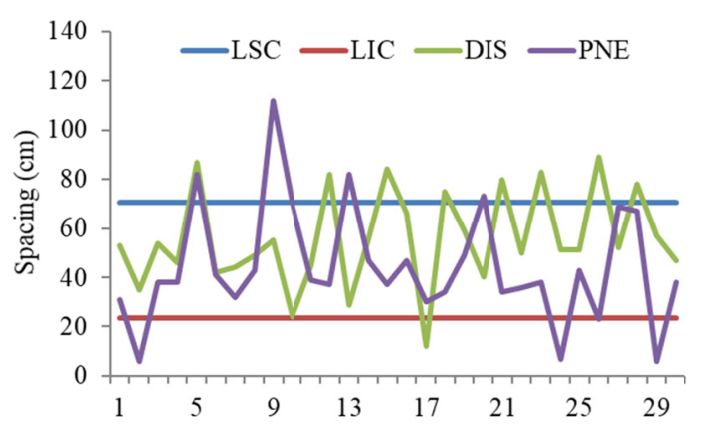

Figure 3. Control charts of the equidistance of the plants of the different seed distribution mechanisms at sowing speeds of 4 (a), 6 (b), 8 (c), 10 (d) and $12 \mathrm{~km} \mathrm{~h}^{-1}$ (e) (São José do Rio Claro-MT, 2015)

Perforated disc distribution mechanism tended to show higher indices of faulty spacing than the pneumatic distribution mechanism (Figures 3c-3e). On the other hand, for double spacing, the pneumatic distribution mechanism shows a tendency of larger values than the perforated disk distribution mechanism (Figures 3a-3e), which can be explained by the fact that besides being of low density, the sunflower seed does not have homogeneous sizes, therefore, impairing the allocation of cells in the perforated disk distribution mechanism, but facilitating the suction of two seeds in a cell in the pneumatic distribution mechanism. 
Another factor that can be observed in the control charts is the disparity of the rows as the speed of tractor-seeder set increases (Figures 3a-3e), which demonstrates that at increasing displacement speed, the equidistance between plants is affected, contrary to the ideal velocity conditions, which is where the furrow is opened and closed without exaggerating soil removal, allowing seeds to be distributed with constant spacing and depth since the increase of the displacement speed influences the reduction of the stand and, consequently, the crop yield (Furlani, Lopes, Abrahão, \& Leite, 1999; Silva et al., 2000; Mello, Furlani, Silva, Lopes, \& Borsatto, 2007). The best result was obtained at the lowest speed, agreeing with Garcia, Jasper, Jasper, Fornari, and Blum (2006) and Dias, Alonço, Baumhardt, and Bonotto (2009), because as the displacement speed increases, the rotation speed of the distribution discs is proportionally increased, which reduces the time available for filling the furrows with seeds (Bottega et al., 2014).

In the study conducted in São José do Rio Claro (MT), it was observed that the slower the tractor-sower set displacement speed, the greater the precision in uniform seed distribution (plantability), with direct effects on sunflower agronomic characteristics.

\section{Conclusions}

Regardless of the seed distribution mechanism, the rise in sowing speed caused a reduction in plant population by changing plant height, head height, head mass, achene mass per head, mass of a thousand achenes and head diameter.

The perforated disk distributing mechanism had the best performance in acceptable spacings and the pneumatic one provided greater guarantee of desired plant population.

The different distribution mechanisms, as well as different sowing speeds, did not influence achenes yield.

The farmer should be aware of the speed of sowing adopted in his sunflower crop, as increasing speeds may affect uniform seed distribution as well as plant development.

\section{Acknowledgements}

The authors would like to thank the Research Group in Phytotechny (GPF) of the Federal Institute of Education, Science and Technology of Mato Grosso (IFMT)-Campus Campo Novo do Parecis, for its help and funding.

\section{References}

ABNT (Associação Brasileira de Normas Técnicas). (1995). Projeto de norma 04: 015.06-007: Semeadora semeadora adubadora ensaios de campo método de ensaio (p. 12). São Paulo, Brazil.

Alonço, A. S., Silveira, H. A. T., Cardinal, K. M., \& Rist, G. R. (2015). Distribuição longitudinal de semente de algodão e girassol com diferentes velocidades e inclinações em dosadores pneumáticos. Scientia Agraria, 16(2), 63-70. https://doi.org/10.5380/rsa.v16i2.41050

Bezerra, F. T. C., Dutra, A. S., Bezerra, M. A. F., Oliveira Filho, A. F., \& Barros, G. L. (2014). Comportamento vegetativo e produtividade de girassol em função do arranjo espacial das plantas. Revista Ciência Agronômica, 45(2), 335-343.

Bottega, E. L., Rosolem, D. H., Oliveria Neto, A. M. de, Piazzetta, H. von L., \& Guerra, N. (2014). Qualidade da semeadura do milho em função do sistema dosador de semente e velocidade de operação. Global Science and Technology, 7(1), 107-114.

Castro, C. de, Junior, A. de O., Oliveira, F. A. de, Leite, R. M. V. B. C., \& Rodak, B. W. (2011). Avaliação do arranjo de plantas de girassol (pp. 241-245). Reunião nacional de pesquisa de girassol, 7th. Aracaju, Brazil.

Dalchiavon, F. C., Lorenzon, L. A., Perina, R. de A., Oliveira, R. A. de, \& Santos, J. A. dos. (2019). Economic Opportunity for Investment in Soybean and Sunflower Crop System in Mato Grosso, Brazil. Journal of Experimental Agriculture International, 29(5), 1-12. https://doi.org/10.9734/JEAI/2019/45695

Dalchiavon, F. C., Malacarne, B. J., \& Carvalho, C. G. P. (2016). Características agronômicas de genótipos de girassol (Helianthus annuus L.) em segunda safra no chapadão do Parecis-MT. Revista de Ciências Agrárias, 39(1), 178-186. https://doi.org/10.19084/RCA15049

Dias, V. O. D., Alonço, A. S., Baumhardt, U. B., \& Bonotto, G. J. (2009). Distribuição de sementes de milho e soja em função da velocidade e densidade de semeadura. Ciência Rural, 39(6), 1721-1728. https://doi.org/ 10.1590/S0103-84782009005000105

EMBRAPA (Empresa Brasileira de Pesquisa Agropecuária). (2018). Sistema brasileiro de classificação de solos (5nd ed., p. 590). Brasília, DF: Embrapa. 
Ferreira, D. F. (2011). Sisvar: A computer statistical analysis system. Ciencia e Agrotecnologia, 35(6), 1039-1042. https://doi.org/10.1590/S1413-70542011000600001

Furlani, C. E. A., Lopes, A., Abrahão, F. Z., \& Leite, M. A. S. (1999). Características da cultura do milho (Zea mays L.) em função do tipo de preparo do solo e da velocidade de semeadura. Engenharia Agrícola, 19(2), 177-186.

Furtado, G. F., \& Chaves, L. H. G. (2018). Growth Rates and Sunflower Production in Function of Fertilization with Biochar and NPK. Journal of Agricultural Science, 10(2). 260-270. https://doi.org/10.5539/ jas.v10n2p260

Garcia, L. C., Jasper, R., Jasper, M., Fornari, A. J., \& Blum, J. (2006). Influência da velocidade de deslocamento na semeadura do milho. Engenharia Agrícola, 26(2), 520-527. https://doi.org/10.1590/S0100-691620060 00200021

Garcia, R. F., Vale, W. G., Oliveira, M. T. R., Pereira, E. M., Amim, R. T., \& Braga, T. C. (2011). Influência da velocidade de deslocamento no desempenho de uma semeadora-adubadora de precisão no Norte Fluminense. Acta Scientiarum Agronomy, 33(3), 417-422. https://doi.org/10.4025/actasciagron.v33i3.6085

Krzyzanowski, F. C., França-Neto, J. B., Hennning, A. A., \& Costa, N. P. (2008). A semente de soja como tecnologia e base para altas produtividades (Circular Técnica 55, p. 7). Londrina: Embrapa Soja.

Mello, A. J. R., Furlani, C. E. A., Silva, R. P., Lopes, A., \& Borsatto, E. A. (2007). Produtividade de híbridos de milho em função da velocidade de semeadura. Engenharia Agrícola, 27(2), 479-486. https://doi.org/ 10.1590/S0100-69162007000300017

Pimentel, G. F. P., \& Garcia, C. H. (2002). Estatística aplicada à experimentos agronômicos e florestais (p. 309). Piracicaba: FEALQ.

Pinheiro Neto, R. P., Braccini, A. de L., Scapim, C. A., Bortolotto, V. C., \& Pinheiro, A. C. (2008). Desempenho de mecanismos dosadores de sementes em diferentes velocidades e condições de cobertura do solo. Acta Scientiarum Agronomy, 30, 611-617. https://doi.org/10.4025/actasciagron.v30i5.5960

Portella, J. A. (2001). Semeadoras para plantio direto (p. 252). Viçosa: Aprenda Fácil.

Rosa, D. P. da, Toniasso, A. M., Santos, C. C. dos, Pagnussat, L., Alflen, J. A., \& Bruinsma, M. L. (2012). Distribuição de sementes com a tecnologia rampflow (p. 9). IFRS, Sertão-RS.

Silva, J. G., Kluthcouski, J., \& Silveira, P. M. (2000). Desempenho de uma semeadora-adubadora no estabelecimento e na produtividade da cultura do milho sob plantio direto. Scientia Agrícola, 57(1), 7-12. https://doi.org/10.1590/S0103-90162000000100003

Silva, M. C., \& Gamero, C. A. (2010). Qualidade da operação de semeadura de uma semeadora-adubadora de plantio direto em função do tipo de martelete e velocidade de deslocamento. Revista Energia na Agricultura, 25(1), 85-102. https://doi.org/10.17224/EnergAgric.2010v25n1p85-102

Siqueira, R., \& Casão Junior, R. (2002). Dinâmica de semeadoras adubadoras diretas em Entre Rios do Oeste-PR. Londrina-PR: IAPAR.

Tourino, M. C., \& Klingensteiner, P. (1983). Ensaio e avaliação de semeadoras-adubadoras (pp. 03-116). Congresso Brasileiro de Engenharia Agrícola, Rio de Janeiro.

Trogello, E., Modolo, A. J., Dallacort, R., Baesso, M. M., \& Scarsi, M. (2014). Desenvolvimento do milho sobre diferentes manejos de palhada, sulcadores, e velocidades de semeadura. Revista Brasileira de Milho e Sorgo, 13(2), 142-153. https://doi.org/10.18512/1980-6477/rbms.v13n2p142-153

Vale, W. G., Garcia, R. F., Corrêa Júnior, D., Gravina, G. A., Klaver, P. P. C., \& Vasconcelos Júnior, J. F. S. (2010). Influência da velocidade de deslocamento no desempenho de uma semeadora-adubadora direta. Global Science and Technology, 3(3), 67-74.

\section{Copyrights}

Copyright for this article is retained by the author(s), with first publication rights granted to the journal.

This is an open-access article distributed under the terms and conditions of the Creative Commons Attribution license (http://creativecommons.org/licenses/by/4.0/). 